\title{
Vibrio tapetis from wrasse used for ectoparasite bio-control in salmon farming: phylogenetic analysis and serotyping
}

\author{
Snorre Gulla ${ }^{1,2, *}$, Anita Rønneseth ${ }^{3}$, Henning Sørum ${ }^{4}$, Øyvind Vågnes ${ }^{2}$, \\ Sabela Balboa ${ }^{5}$, Jesús L. Romalde ${ }^{5}$, Duncan J. Colquhoun ${ }^{1,3}$ \\ ${ }^{1}$ Norwegian Veterinary Institute, Pb 750 Sentrum, 0106 Oslo, Norway \\ ${ }^{2}$ Vaxxinova Norway AS, Kong Christian Fredriks plass 3, 5006 Bergen, Norway \\ ${ }^{3}$ Department of Biology, University of Bergen, Pb 7800, 5020 Bergen, Norway \\ ${ }^{4}$ Department of Food Safety and Infection Biology, Norwegian University of Life Sciences, Pb 8146, Dep 0033 Oslo, Norway \\ ${ }^{5}$ Department of Microbiology and Parasitology, CIBUS-Faculty of Biology, Universidade de Santiago de Compostela, \\ 15782 Santiago de Compostela, Spain
}

\begin{abstract}
So-called 'cleaner fish', including various wrasse (Labridae) species, have become increasingly popular in Norwegian salmon farming in recent years for biocontrol of the salmon louse Lepeophtheirus salmonis. Cleaner fish mortalities in salmon farms are, however, often high. Various bacterial agents are frequently associated with episodes of increased cleaner fish mortality, and Vibrio tapetis is regularly cultured from diseased wrasse. In the present study, we investigated the genetic relationships among $54 \mathrm{~V}$. tapetis isolates (34 from wrasse species) by multilocus sequence analysis (MLSA; rpoD, ftsZ, pyrH, rpoA and atpA). In the resulting phylogenetic tree, all wrasse isolates belonged to sub-clusters within $V$. tapetis subsp. tapetis. Slide agglutination testing further confirmed the complete dominance amongst these isolates of $4 \mathrm{O}$-antigen serotypes, designated here as $V$. tapetis subsp. tapetis serotypes O1, O3, O4 and O5, respectively. A pilot challenge trial using serotypes $\mathrm{O} 3, \mathrm{O} 4$ and $\mathrm{O} 5$ did not indicate high pathogenicity towards ballan wrasse Labrus bergylta, thus questioning the role of $V$. tapetis as a primary pathogen of this fish species.
\end{abstract}

KEY WORDS: Vibrio tapetis - Multilocus sequence analysis · Serotyping - Infection trial • Cleaner fish $\cdot$ Wrasse $\cdot$ Salmon louse $\cdot$ Biocontrol

\section{INTRODUCTION}

The use of 'cleaner fish' as biological control agents of salmon louse Lepeophtheirus salmonis has become an integral part of salmon farming in many regions along the Norwegian coast. Wild-caught wrasse (Labridae) of various species dominate, with over 15 million fish captured for this purpose in 2014 (Norwegian Directorate of Fisheries 2015). The main wrasse species utilised are goldsinny Ctenolabrus

\footnotetext{
${ }^{*}$ Corresponding author: snorre.gulla@vetinst.no
}

rupestris, ballan Labrus bergylta, and corkwing Symphodus melops. Farming of ballan wrasse and lumpsucker Cyclopterus lumpus has also been initiated to meet the growing demand for cleaner fish.

High mortality levels constitute a major obstacle to sustained use of cleaner fish in Norwegian aquaculture (Nilsen et al. 2014), both in terms of animal welfare and in regard to extensive exploitation of autochthonous and largely uncharted wild wrasse populations (Skiftesvik et al. 2015). Bacterial infec-

() The authors 2017. Open Access under Creative Commons by Attribution Licence. Use, distribution and reproduction are unrestricted. Authors and original publication must be credited. 
tions are among the most common diagnostic findings following investigation of cleaner fish mortalities (Johansen 2013, Hjeltnes 2014, Bornø \& Lie Linaker 2015).

Vibrio tapetis is among the bacterial agents more regularly cultured from moribund and dead wrasse of all species used as cleaner fish in Norway. While perhaps best known as the causative agent of brown ring disease in clams (Paillard 2004), this bacterium has also been associated with disease in various wild and cultivated marine fish species (Reid et al. 2003, López et al. 2011, Declercq et al. 2015, Levican et al. 2017), including corkwing wrasse (Jensen et al. 2003, Bergh \& Samuelsen 2007).

As sustainable production of farmed cleaner fish will presumably depend upon development of effective vaccines against bacterial pathogens, identification and confirmation of the pathogenic nature of relevant bacterial species is necessary. It remains uncertain whether $V$. tapetis constitutes a true pathogen of wrasse species used as cleaner fish, and only one such isolate (from corkwing wrasse) has to date been characterised (Jensen et al. 2003). In order to facilitate selection of representative strains for further investigation, the primary aim of the present study was to examine the genetic and antigenic relationships amongst $V$. tapetis isolates recovered from wrasse. A number of isolates from these fish and other hosts were characterised using multilocus sequence analysis (MLSA) and serotyping. A preliminary infection challenge trial in ballan wrasse was also conducted.

\section{MATERIALS AND METHODS}

\section{Bacterial strains and culture conditions}

Gene sequence information for MLSA from $54 \mathrm{Vib}$ rio tapetis isolates, including 34 from wrasse, was obtained by sequencing or via GenBank. Isolates sequenced in our laboratory derived primarily from diagnostic investigations at the Norwegian Veterinary Institute (NVI) during the period 2009 to 2013. Selected strains acquired from reference laboratories were also included. Information on all examined isolates can be found in Table 1.

Primary cultures $(5 \%$ bovine blood agar with $2 \%$ $\mathrm{NaCl} ; \mathrm{BA} 2 \%$ ) were predominantly obtained by aseptic culture of head kidney tissues from deceased or moribund fish, incubated at $15^{\circ} \mathrm{C}$ for up to $1 \mathrm{wk}$. Subsequent identification of secondary pure cultures as $V$. tapetis consisted of phenotypic characterisation
(Table 2). This biochemical analysis was in some cases (e.g. due to ambiguous/discrepant profiles) supplemented with partial 16S rDNA sequencing.

Isolates/strains cryopreserved on heart infusion broth (with $20 \%$ glycerol and $2 \% \mathrm{NaCl}$ ) at $-80^{\circ} \mathrm{C}$ were revived on $\mathrm{BA} 2 \%$ at $15^{\circ} \mathrm{C}$ for 2 to $3 \mathrm{~d}$. Infection trial cultures were produced in heart infusion broth supplemented with $2 \% \mathrm{NaCl}$ (HIB2\%) as follows:

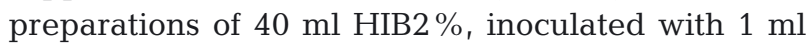
HIB2 \% overnight culture, were incubated overnight at $15^{\circ} \mathrm{C}$ with shaking (150 rpm). The cultures were then centrifuged at $3283 \times g$ for $10 \mathrm{~min}$, the supernatant discarded, and the pellet re-suspended in physiological saline to an absorbance of approximately 1.0 at $600 \mathrm{~nm}$. Following another centrifugation step (3283 $\times g$ for $5 \mathrm{~min}), 30 \%$ of the supernatant was discarded, the pellet re-suspended, and serial dilutions with physiological saline made on ice (tenfold; undiluted to $10^{-8}$ ).

\section{DNA extraction, PCR and sequencing}

Genomic DNA was extracted by boiling a single bacterial colony in distilled water $\left(\mathrm{dH}_{2} \mathrm{O}\right)$ for $7 \mathrm{~min}$, followed by centrifugation and use of the supernatant as a PCR template. Housekeeping gene target loci consisted of partial sequences of the genes encoding RNA polymerase $\sigma$-factor (rpoD), cell division protein (ftsZ), uridylate kinase $(p y r H)$, RNA polymerase $\alpha$-subunit (rpoA) and $\alpha$-subunit of bacterial ATP synthase $(a t p A)$. Housekeeping gene PCR (primers, setup and thermal cycling conditions) and sequencing was conducted as previously described (Gulla et al. 2015). Partial 16S rDNA sequencing of selected isolates was conducted as described by Suau et al. (1999).

\section{Sequence analysis}

Contigs were assembled (Geneious v.7.1; Biomatters), trimmed and adjusted (MEGA6; Tamura et al. 2013), aligned (ClustalX; Larkin et al. 2007) and concatenated as previously described (Gulla et al. 2015). The housekeeping gene sequences, following trimming, were 579 bp (rpoD), 480 bp (ftsZ), 456 bp $($ pyrH) $492 \mathrm{bp}($ rpoA) and $639 \mathrm{bp}(\operatorname{atp} A)$, resulting in concatenated sequences of $2646 \mathrm{bp}$. Upon identification of identical concatenated sequences in multiple isolates from individual clinical cases (presumably clones), only single representatives from each case were included in further analyses. Partial 16S rDNA 
Table 1. Vibrio tapetis isolates/strains examined in the present study. For sequence accession numbers, see Table S1 in the Supplement at www.int-res.com/articles/suppl/d125p189_supp.pdf. NVI-prefix: strains recovered and cryopreserved $\left(-80^{\circ} \mathrm{C}\right)$ at the Norwegian Veterinary Institute

\begin{tabular}{|c|c|c|c|c|c|}
\hline $\begin{array}{l}\text { Strain/ } \\
\text { isolate ID }\end{array}$ & $\begin{array}{c}V . \text { tapetis } \\
\text { subspecies }\end{array}$ & $\begin{array}{l}V . \text { tapetis } \\
\text { serotype }\end{array}$ & $\begin{array}{l}\text { Biological } \\
\text { origin }\end{array}$ & $\begin{array}{c}\text { Geographical } \\
\text { origin }\end{array}$ & $\begin{array}{c}\text { Year of first } \\
\text { isolation }\end{array}$ \\
\hline СECT4600 & tapetis ${ }^{\mathrm{T}}$ & O1 & Manila clam & France & 1990 \\
\hline LMG19705 & tapetis & O1 & Manila clam & France & 1990 \\
\hline NVI-7077 & tapetis & O1 & Wrasse sp. & Norway & 2009 \\
\hline NVI-7095 & tapetis & O1 & Wrasse sp. & Norway & 2009 \\
\hline NVI-7101 & tapetis & O1 & Corkwing wrasse & Norway & 2009 \\
\hline NVI-8225 & tapetis & O1 & Ballan wrasse & Norway & 2011 \\
\hline NVI-8629 & tapetis & O1 & Goldsinny wrasse & Norway & 2012 \\
\hline GR0202RD & tapetis & $\mathrm{O} 2$ & Grooved carpet shell & Spain & 1994 \\
\hline NVI-7583 & tapetis & O3 & Corkwing wrasse & Norway & 2010 \\
\hline NVI-7627 & tapetis & O3 & Ballan wrasse & Norway & 2010 \\
\hline NVI-8137 & tapetis & O3 & Atlantic halibut & Norway & 2011 \\
\hline NVI-9247 & tapetis & O3 & Goldsinny wrasse & Norway & 2013 \\
\hline NVI-6909 & tapetis & $\mathrm{O} 4$ & Turbot & Norway & 2009 \\
\hline NVI-7076 & tapetis & $\mathrm{O} 4$ & Wrasse sp. & Norway & 2009 \\
\hline NVI-7596 & tapetis & $\mathrm{O} 4$ & Goldsinny wrasse & Norway & 2010 \\
\hline NVI-7610 & tapetis & $\mathrm{O} 4$ & Ballan wrasse & Norway & 2010 \\
\hline NVI-7655 & tapetis & $\mathrm{O} 4$ & Corkwing wrasse & Norway & 2010 \\
\hline NVI-7684 & tapetis & $\mathrm{O} 4$ & Ballan wrasse & Norway & 2010 \\
\hline NVI-8065 & tapetis & $\mathrm{O} 4$ & Corkwing wrasse & Norway & 2011 \\
\hline NVI-8131 & tapetis & $\mathrm{O} 4$ & Corkwing wrasse & Norway & 2011 \\
\hline NVI-8160 & tapetis & $\mathrm{O} 4$ & Corkwing wrasse & Norway & 2011 \\
\hline NVI-8188 & tapetis & $\mathrm{O} 4$ & Atlantic salmon & Norway & 2011 \\
\hline NVI-8624 & tapetis & $\mathrm{O} 4$ & Goldsinny wrasse & Norway & 2012 \\
\hline NVI-8633 & tapetis & $\mathrm{O} 4$ & Wrasse sp. & Norway & 2012 \\
\hline NVI-8696 & tapetis & $\mathrm{O} 4$ & Wrasse sp. & Norway & 2010 \\
\hline NVI-8706 & tapetis & $\mathrm{O} 4$ & Corkwing wrasse & Norway & 2011 \\
\hline NVI-9149 & tapetis & $\mathrm{O} 4$ & Wrasse sp. & Norway & 2013 \\
\hline LP2 & tapetis & O5 & Corkwing wrasse & Norway & 1999 \\
\hline NVI-6910 & tapetis & O5 & Turbot & Norway & 2009 \\
\hline NVI-7636 & tapetis & O5 & Ballan wrasse & Norway & 2010 \\
\hline NVI-8049 & tapetis & O5 & Corkwing wrasse & Norway & 2011 \\
\hline NVI-8080 & tapetis & O5 & Wrasse sp. & Norway & 2011 \\
\hline NVI-8102 & tapetis & O5 & Goldsinny wrasse & Norway & 2011 \\
\hline NVI-8134 & tapetis & O5 & Corkwing wrasse & Norway & 2011 \\
\hline NVI-8197 & tapetis & O5 & Ballan wrasse & Norway & 2011 \\
\hline NVI-8280 & tapetis & O5 & Goldsinny wrasse & Norway & 2012 \\
\hline NVI-8359 & tapetis & O5 & Wrasse sp. & Norway & 2012 \\
\hline NVI-8414 & tapetis & O5 & Wrasse sp. & Norway & 2012 \\
\hline NVI-8663 & tapetis & O5 & Ballan wrasse & Norway & 2012 \\
\hline NVI-8694 & tapetis & O5 & Wrasse sp. & Norway & 2010 \\
\hline NVI-8741 & tapetis & O5 & Ballan wrasse & Norway & 2012 \\
\hline a200 & tapetis & Not typed & Wedge sole & Spain & 2005 \\
\hline B11.1 & tapetis & Not typed & Manila clam & France & 1991 \\
\hline C0620701B & tapetis & Not typed & Shi drum & Spain & 2007 \\
\hline $\mathrm{C} 0620701 \mathrm{H}$ & tapetis & Not typed & Shi drum & Spain & 2007 \\
\hline C0620701R & tapetis & Not typed & Shi drum & Spain & 2007 \\
\hline СЕСТ8161 & britannicus $^{\mathrm{T}}$ & Unnamed & Atlantic halibut & Scotland & 2001 \\
\hline 102 & britannicus & Not typed & Manila clam seed & Ireland & 2005 \\
\hline 127 & britannicus & Not typed & Manila clam & Ireland & 2005 \\
\hline NVI-8537 & britannicus & $\mathrm{O} 2$ & Lumpsucker & Norway & 2012 \\
\hline NVI-8139 & britannicus & $\mathrm{O} 3$ & Atlantic halibut & Norway & 2011 \\
\hline NVI-8626 & Unnamed & No reaction & Atlantic halibut & Norway & 2012 \\
\hline NVI-8833 & Unnamed & No reaction & Atlantic halibut & Norway & 2013 \\
\hline NVI-8834 & Unnamed & No reaction & Atlantic halibut & Norway & 2013 \\
\hline
\end{tabular}


Table 2. Phenotypic profile usually associated with fishrelated Vibrio tapetis isolates recovered at the Norwegian Veterinary Institute (NVI). O/F: aerobic/anaerobic production of acid from glucose; A/L/O: production of arginine dihydrolase, lysine decarboxylase and/or ornithine decarboxylase

Culture characteristics: Grows well on $5 \%$ bovine blood agar with $2 \% \mathrm{NaCl}$ within $2-3 \mathrm{~d}$ when incubated at 15 and $22^{\circ} \mathrm{C}$. Slower growth with $0.5 \% \mathrm{NaCl}$

General morphology: 1-3 mm grey/off-white, opaque colonies, usually with weak haemolysis extending only 1-2 mm beyond colony border

Microscopy: Motile rods, often curved or pleomorphic. Gram-negative

\begin{tabular}{lcc}
\hline Biochemical test & $\begin{array}{c}\text { Typical } \\
\text { reaction }\end{array}$ & $\begin{array}{c}\text { NVI-isolates } \\
\text { displaying } \\
\text { reaction }(\%)\end{array}$ \\
\hline O/F & $+/+$ & 100 \\
Vibriostat O/129 & $\begin{array}{c}\text { Sensitive } \\
\text { A/L/O }\end{array}$ & 100 \\
Production of & + & 100 \\
Oxidase & + & 100 \\
Alginase & + & 89 \\
Gelatinase & + & 90 \\
Indole & - & 95 \\
Acid production from & - & 100 \\
Arabinose & - & 79 \\
Cellobiose & - & 100 \\
Lactose & + & 95 \\
Mannitol & + & 100 \\
Mannose & + & 86 \\
Sucrose & & 100 \\
Trehalose & &
\end{tabular}

sequences (432 bp) were not included in the concatenated analysis. Maximum likelihood (ML) trees based on DNA sequences were constructed (PhyML v.3.0; Guindon et al. 2010) and edited (MEGA6), and selection pressures were evaluated (codon-based $Z$-test in MEGA6), as previously described (Gulla et al. 2015). Additionally, ML trees based on translated housekeeping genes were also constructed using default settings in PhyML v.3.0. Colour-coded concatenated and single gene trees were visually checked for discrepant clustering patterns indicating possible recombination events.

For each unique concatenated sequence type, the complete set of partial housekeeping gene sequences from a single representative isolate was submitted to GenBank (see Table S1 in the Supplement at www.int-res.com/articles/suppl/d125p189_supp. pdf; accession numbers KU901706-KU901711 and KU925503-KU925562).

\section{Antisera production and serotyping}

Three isolates from ballan wrasse (NVI-7627, NVI7684 and NVI-8197), each representing a distinct cluster following MLSA of concatenated sequences, were cultured on BA2 \% as described above. Bacterial cell preparation, immunisation of rabbits, antisera collection and slide agglutination were conducted essentially as previously described (Gulla et al. 2015). Additionally, antisera against 3 published (Balboa et al. 2006, Declercq et al. 2015) V. tapetis serotypes - subsp. tapetis serotypes O1 (strain CECT$4600^{\mathrm{T}}$ ) and O2 (strain GR0202RD), and the subsp. britannicus serotype (strain CECT8161 ${ }^{\mathrm{T}}$ ) - were also employed for comparison. Briefly, slide agglutination testing consisted of mixing $15 \mu$ l bacterial cells (suspended in formalin buffer and heat-inactivated by $1 \mathrm{~h}$ boiling) with $15 \mu \mathrm{l}$ antiserum on glass slides. Visible agglutination of bacterial cells within $1 \mathrm{~min}$ of gentle rocking was registered as a positive reaction. Naïve rabbit antiserum was used to test for autoagglutination. Based on this, novel serotype designations were awarded as a continuation of the system previously used for this species (Balboa et al. 2006, Declercq et al. 2015).

\section{Pilot challenge trial}

The challenge trial was authorised in 2013 by the Norwegian Animal Research Authority (experiment ID 5690), and conducted the same year. Experimental fish (farmed ballan wrasse; $~ 30 \mathrm{~g}$ ) with no prior disease history were transported from a cultivation facility in Western Norway to the challenge facilities at the University of Bergen, and acclimatised in a $500 \mathrm{l}$ tank for $9 \mathrm{~d}$ following delivery. Throughout the experiment, temperature $\left(14^{\circ} \mathrm{C}\right)$ and salinity $(34 \%$ $\mathrm{NaCl}$ ) of tank water was kept constant, and oxygen saturation of outlet water was $\geq 77 \%$. Filtered seawater was used, and the water flow-through rates were 300 and $400 \mathrm{l} \mathrm{h}^{-1}$, respectively, in the 150 and $500 \mathrm{l} \mathrm{tanks}$ (see below). A light regimen of $12 \mathrm{~h}$ light: $12 \mathrm{~h}$ dark was used. Lengths of plastic pipe, mimicking natural shelters, were installed in all experimental tanks to improve welfare and reduce stress. Throughout the experiment, the fish were fed daily with feed supplied by the farm of origin, but were fasted for $24 \mathrm{~h}$ prior to challenge.

The 3 strains used for production of antisera (NVI7627, NVI-7684 and NVI-8197) were also used for challenge trials. Following culturing and serial dilution as previously described, fish anesthetised in 
$80 \mathrm{mg} \mathrm{l}^{-1}$ metacain (Finquel vet.) were injected intraperitoneally (i.p.) with $100 \mu \mathrm{l}$ bacterial suspension and simultaneously marked subcutaneously under the jaw with an injection of colour coded fluorescent dye (VIE tags, North West Marine Technology). Three different doses per isolate were used (undiluted, $10^{-2}$ and $10^{-4}$; subsequently referred to as high-, medium- and low-dose, respectively). To retrospectively calculate infection doses, $100 \mu \mathrm{l}$ from dilutions $10^{-5}, 10^{-6}, 10^{-7}$ and $10^{-8}$ were spread in duplicate on BA2\% plates and cultured (as previously described) prior to counting of colony forming units (CFU).

A total of 5 fish per dose per isolate were infected and distributed amongst three $150 \mathrm{l}$ tanks (1 tank per strain), each of which also contained 10 unchallenged cohabitants (see Table S2). Five randomly selected unchallenged fish were also sampled at this point (bacteriological culturing from head kidney; see below), and 50 fish were left untreated as negative controls in the $500 \mathrm{l}$ acclimation tank. Upon initiation of the experiment, fish densities were thus 5 and $3 \mathrm{~g} \mathrm{l}^{-1}$ in challenge and control tanks, respectively. The tanks were checked twice daily for mortalities, and bacteriological samples, taken on BA2\% from aseptically exposed head kidneys, were immediately obtained from dead fish. Mortalities were also subjected to external and internal visual (macroscopic) examination to check for signs of disease. The experiment was terminated $21 \mathrm{~d}$ after infection and all surviving fish were euthanised. All surviving i.p. infected fish, and a representative selection of cohabitants and control fish, were macroscopically and bacteriologically examined (as for mortalities).

\section{RESULTS}

\section{Sequence analysis and serotyping}

Analysis of concatenated nucleotide sequences ascertained the existence of 1 major and 2 minor genetic clusters in our material (Fig. 1a). All wrasse isolates belonged to the major cluster which also included the Vibrio tapetis subsp. tapetis (Balboa \& Romalde 2013) type strain $\left(\mathrm{CECT} 4600^{\mathrm{T}}\right)$. A minor cluster was identified around $V$. tapetis subsp. britannicus (Balboa \& Romalde 2013). The remaining minor cluster did not comprise any previously described strains, with all 3 associated isolates originating from farmed Atlantic halibut Hippoglossus hippoglossus (juveniles) in Norway. Members of this cluster displayed 2 unique single nucleotide polymorphisms
(SNPs) in the analysed 16S rDNA region, which was otherwise conserved amongst all other isolates examined (see Fig. S1 in the Supplement). Individual analysis of housekeeping genes revealed clustering patterns largely consistent with the concatenated analysis.

Pairwise sequence identities (PID) for concatenated housekeeping gene DNA sequences were $\geq 94.9 \%$ for the material as a whole, and increased to $\geq 98.6 \%$ when analysis was restricted to the subsp. tapetis cluster. Sequence heterogeneity was dominated by synonymous mutations and purifying selection pressures were identified at all 5 loci $(\mathrm{p}<0.01)$, with average $\left(\mathrm{d}_{\mathrm{S}}-\mathrm{d}_{\mathrm{N}}\right)$ values of $7.0(\mathrm{rpoD}), 7.9(\mathrm{fts} Z)$, $7.5\left(\right.$ pyrH), $3.0\left(\right.$ rpoA) and $4.7(\operatorname{atp} A)\left(\right.$ where $\mathrm{d}_{\mathrm{S}}\left[\mathrm{d}_{\mathrm{N}}\right]=$ no. of [non]synonymous substitutions per [non]synonymous site. Despite the dominance of synonymous substitutions, analysis of concatenated protein sequences revealed some variation within the subsp. tapetis cluster (Fig. 1b).

Slide agglutination testing revealed associations between $\mathrm{O}$-antigen serotype and concatenated sequence type, although a few isolates (most notably NVI-8139 and NVI-8537) displayed serotypes in discordance with their phylogenetic affiliation (Fig. 1). None of the isolates tested by slide agglutination reacted with more than one antiserum, nor was any auto-agglutination observed. Three novel $V$. tapetis subsp. tapetis O-antigen serotypes, i.e. O3, O4 and $\mathrm{O} 5$, are proposed for strains displaying agglutination with antiserum raised against NVI-7627, NVI-7684 or NVI-8197, respectively. The 34 wrasse isolates were distributed amongst subsp. tapetis serotypes O1 ( $\mathrm{n}=$ 5), O3 ( $\mathrm{n}=3), \mathrm{O} 4(\mathrm{n}=13)$ and O5 $(\mathrm{n}=13)$.

In order to evaluate the taxonomic resolution of individual housekeeping genes, PID ranges were registered for the subsp. tapetis cluster (intracluster), as well as for this cluster versus the 2 minor clusters (inter-cluster). While intra-cluster PID ranges were $\geq 96.4 \%(r p o D), \geq 99.0 \%$ (ftsZ), $\geq 99.3 \%(p y r H)$, $100 \%($ rpoA), $\geq 97.8 \%(\operatorname{atpA})$ and $\geq 98.6 \%$ (MLSA), inter-cluster PID ranges were 91.7 to $94.8 \%(r p o D)$, 92.9 to $94.0 \%$ (ftsZ), 92.5 to $94.1 \%$ (pyrH), 98.6 to $99.0 \%(r p o A), 96.7$ to $99.1 \%(\operatorname{atp} A)$ and 94.9 to $96.0 \%$ (MLSA). As visualised in Fig. 2, this means that with the exception of atpA, individual gene analysis could (within the examined material) reliably distinguish $V$. tapetis subsp. tapetis from non-subsp. tapetis isolates tested (i.e. non-overlapping intra- and intercluster bars). 16S rDNA sequences were not included for such analysis.

Colour-coded single gene- and concatenated (MLSA) trees were compared to enable detection of 

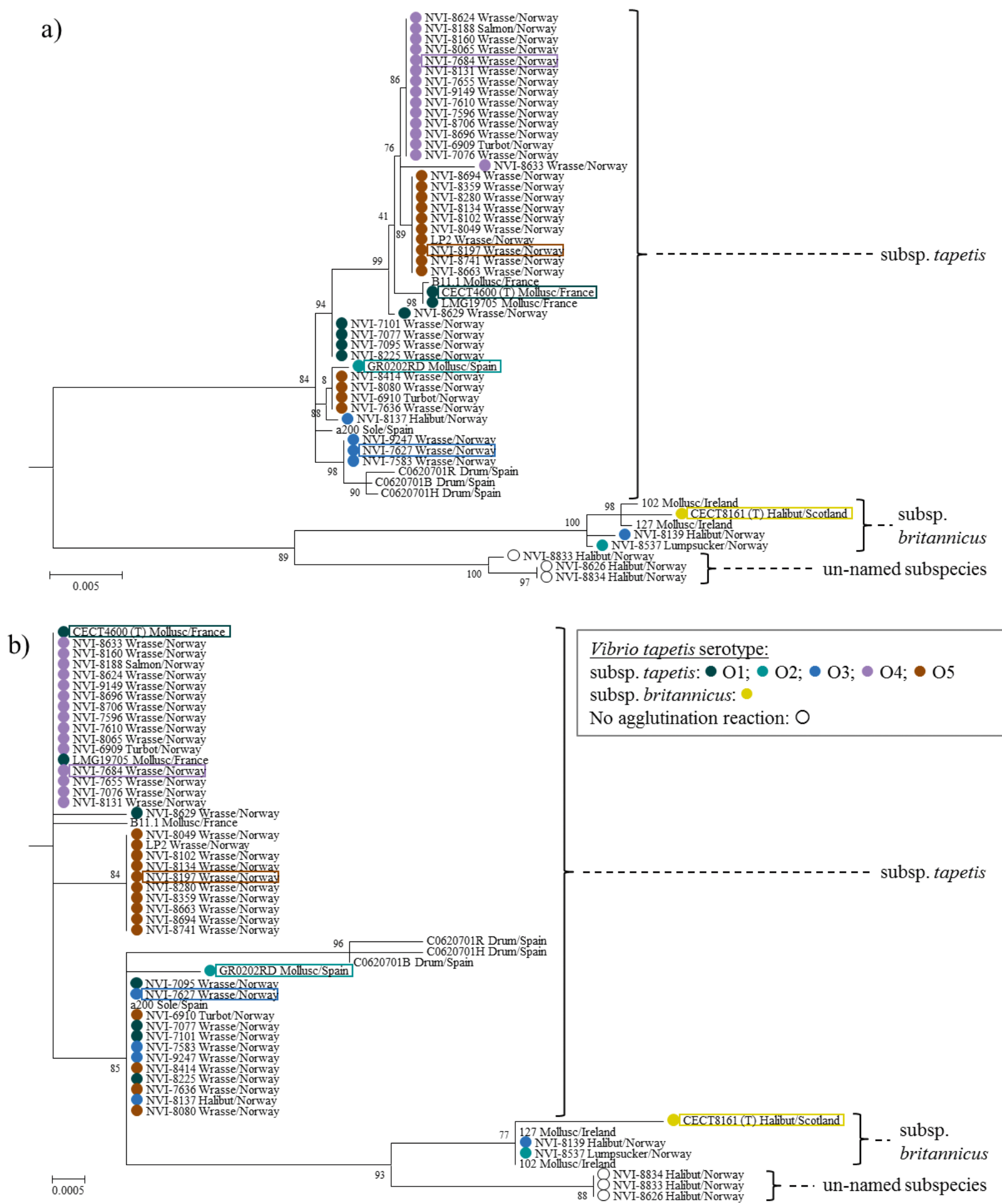

Fig. 1. Maximum likelihood (ML) trees based on concatenated housekeeping gene sequence information $(r p o D, f t s Z, p y r H$, rpoA and atpA) from Vibrio tapetis isolates, with approximate likelihood ratio test (aLRT; Anisimova \& Gascuel 2006) branch support values shown. (a) Tree based on nucleotide sequences; (b) tree based on amino acid sequences. Cluster designations for the 2 named subspecies are given according to Balboa \& Romalde (2013). Isolate ID tags are followed by isolation source (host/geography). The trees were rooted against Vibrio nigripulchritudo strain SFn1 (not shown; accession no. NC_022528). Serotyping results for isolates tested are indicated by colour (see legend), and immunisation strains used for antisera production (Declercq et al. 2015, this study) are colour-framed accordingly 


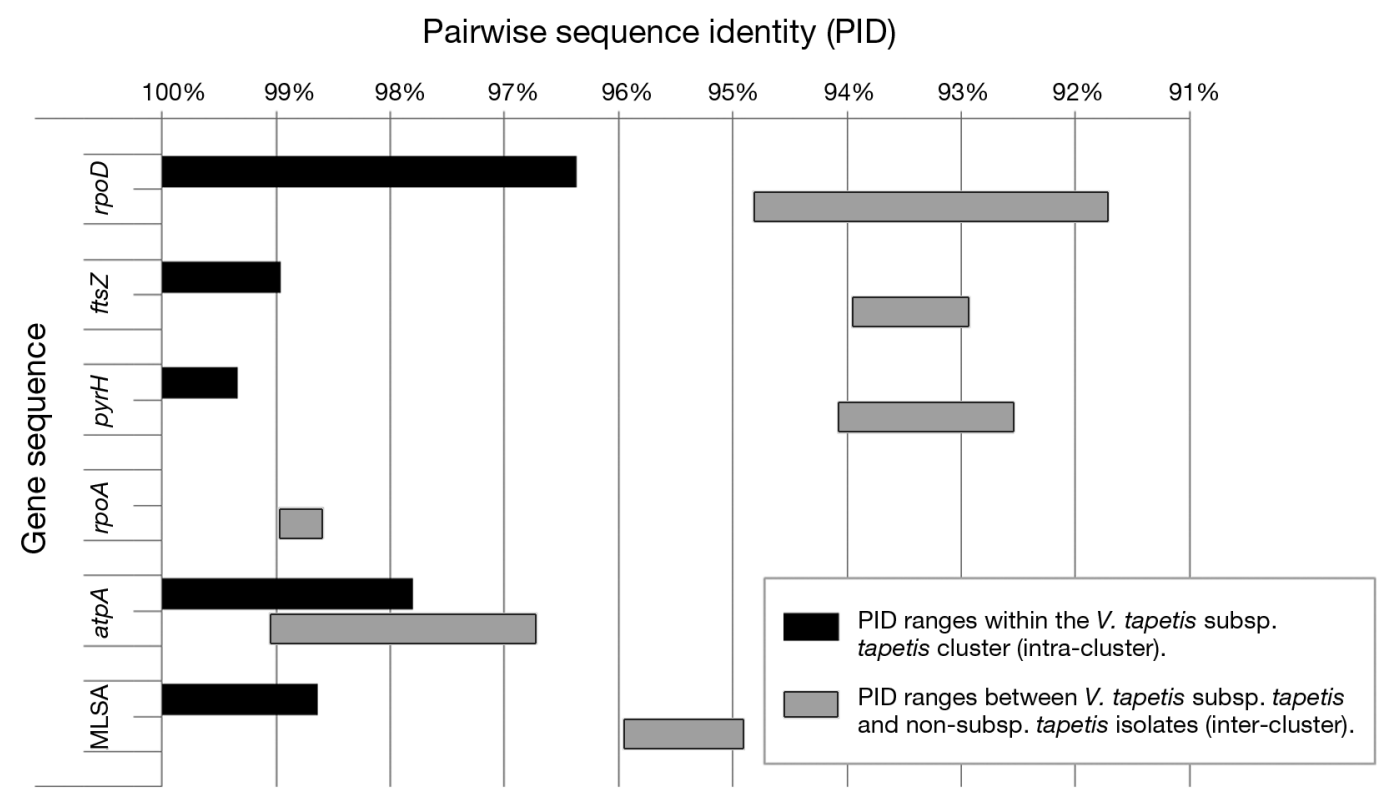

Fig. 2. Intra-cluster (i.e. amongst Vibrio tapetis subsp. tapetis isolates; black bars) and inter-cluster (i.e. subsp. tapetis vs. nonsubsp. tapetis isolates; grey bars) taxonomic resolution of individual genes and concatenated sequences, as determined by pairwise sequence identity (PID)-ranges. Upper and lower bar values represent, respectively, maximum and minimum PIDs. No intra-cluster bar is shown for rpoA, as the analysed region of this gene revealed $100 \%$ identity in all sequenced subsp. tapetis isolates

eventual recombination (see Fig. S2 in the Supplement). No obviously conflicting clustering patterns were observed.

\section{Pilot challenge trial}

No signs of disease nor bacterial infection were observed by visual examination or culturing from randomly selected experimental fish prior to initiation of the challenge trial. No mortalities occurred during the $21 \mathrm{~d}$ trial period in any of the mediumdose, low-dose, cohabitant or control groups. From the high-dose injected groups, $4(80 \%)$ of the fish challenged with strains NVI-7684 and NVI-8197 died within $24 \mathrm{~h}$ after inoculation, and $2(40 \%)$ of the fish challenged with strain NVI-7627 died within $48 \mathrm{~h}$ after inoculation. No further mortality occurred. No macroscopically visible signs of disease were observed in the dead fish (10 in total), but abundant pure culture growth of $V$. tapetis, obtained from head kidney tissues of all mortalities, confirmed systemic bacterial infection. All re-isolated cultures were verified by slide agglutination testing as the respective challenge strains. By visual examination, all survivors appeared healthy upon termination of the experiment, and no bacterial colonies consistent with $V$. tapetis were cultured from sampled survivors (in- cluding i.p. infected fish). Notably, estimates based on CFU counts revealed a log difference with regards to challenge concentrations used for the respective strains (see Table S2).

\section{DISCUSSION}

In the present study, a previously published 5-loci MLSA scheme was used to investigate the genetic relationships of 54 Vibrio tapetis isolates, recovered primarily from diseased wrasse in Norwegian salmon farms. All 34 sequenced isolates from wrasse belonged within the $V$. tapetis subsp. tapetis group, and were further distributed amongst $4 \mathrm{O}$-antigen serotypes. Representative strains for 3 of the serotypes were used in a pilot challenge trial in ballan wrasse, which did not provide a strong indicator for pathogenicity towards this fish species.

Partial regions of the housekeeping genes $r p o D$, $f t s Z$, pyrH, rpoA and atpA were included in this MLSA scheme, which has previously been used to assess the phylogeny of Vibrio splendidus-related bacteria (Gulla et al. 2015). We verified that all of these genes are under purifying selection in $V$. tapetis $(\mathrm{p}<0.01)$, making them suitable as phylogenetic markers (Stackebrandt et al. 2002). Varying taxonomic resolutions (PID-ranges) were observed for the 
individual housekeeping genes (Fig. 2). All but atpA could alone reliably distinguish subsp. tapetis from subsp. britannicus and the other putative subspecies detected (see next paragraph), although full-length analysis of this gene might have increased its discriminatory power (Balboa \& Romalde 2013). Among the examined genes and isolates, $r p o D$ displayed the highest resolution, and rpoA the lowest. No signs of recombination influencing the phylogenetic signal were detected (see Fig. S2 in the Supplement).

All in all, the MLSA expediently resolved the phylogeny of our material, revealing one major cluster comprising the $V$. tapetis subsp. tapetis type strain and all wrasse isolates, as well as 2 minor clusters (Fig. 1a). While one of these minor clusters represents subsp. britannicus (Balboa \& Romalde 2013), the other contains (exclusively) 3 previously undescribed isolates recovered from farmed Atlantic halibut juveniles in Norway. Due to the clear separation of this latter cluster from the other $2(<97 \%$ inter-cluster DNA PID in concatenated housekeeping genes), it presumably represents a presently undescribed $V$. tapetis subspecies. Notably, basic local alignment search tool (BLAST) searches using DNA sequences from the 3 isolates in question revealed $<95 \%$ PID towards available loci ( $r p o D$ and pyrH) from the recently described $V$. tapetis subsp. quintayensis type strain QL-9 ${ }^{\mathrm{T}}$ (Levican et al. 2017), indicating that they do not belong to this novel subspecies.

Slide agglutination testing revealed the complete dominance of 4 subsp. tapetis O-antigen serotypes amongst examined wrasse isolates (Table 1, Fig. 1). This includes the previously described serotype O1 (Balboa et al. 2006, Declercq et al. 2015) in addition to 3 novel serotypes, proposed here as $V$. tapetis subsp. tapetis serotypes O3, O4 and O5. Curiously, 2 Norwegian isolates from lumpsucker (NVI-8537) and Atlantic halibut (NVI-8139), both genetically affiliated with subsp. britannicus, belonged to subsp. tapetis serotypes $\mathrm{O} 2$ and $\mathrm{O} 3$, respectively. This may be due to recombination in $\mathrm{O}$-antigen biosynthesis genes, which has been shown to occur frequently in some Vibrio species (e.g. Wildschutte et al. 2010). The 3 isolates constituting the putative undescribed subspecies showed no agglutination reaction with any of the 6 antisera tested, and presumably represent one or more distinct serotype(s).

The 3 immunisation strains for subsp. tapetis serotypes O3, $\mathrm{O} 4$ and $\mathrm{O} 5$, all of which originate from ballan wrasse, did not appear pathogenic towards this fish species in a preliminary infection trial. This was despite the fact that mortalities between 40 and $80 \%$
( 2 to 4 out of 5 fish) were reached within 2 d after i.p. inoculation in all high-dose groups. Considering the course of the mortalities, however (i.e. acute onset followed by an abrupt cease), we believe that these merely reflect acute toxicity due to the high bacterial concentrations experienced by the high-dose fish. In support of this assumption is the fact that all remaining fish, irrespective of challenge strain/dose, survived through the $21 \mathrm{~d}$ trial without any observable signs of disease. Nor were we able to recover any $V$. tapetis isolates upon termination of the experiment, indicating that i.p. challenged survivors had neutralised the bacteria. Notably, while the experimental fish had no prior history of disease, we cannot decisively rule out the possibility that natural exposure to $V$. tapetis at some earlier time point might have awarded immunity prior to experimental challenge. Unfortunately, the pilot challenges were carried out prior to acquisition of antisera, and serotype O1 was therefore not included in this part of the study.

While our study did not suggest the tested $V$. tapetis serotypes to be pathogenic towards ballan wrasse, despite employing a particularly severe test of virulence (i.p. challenge), it has been previously reported that $V$. tapetis bath challenge may induce mortality in wild-caught corkwing (but not goldsinny) wrasse (Bergh \& Samuelsen 2007). Interpretation of the results in that study was, however, complicated by high mortalities in control groups. The strain used by these investigators was LP2 (subsp. tapetis serotype O5; Table 1, Fig. 1).

Evidently, various $V$. tapetis subspecies/subtypes are present in marine environments in Norway, although only 4 specific subsp. tapetis serotypes have been recovered from clinical cases of wrasse disease (Table 1, Fig. 1). This association may conceivably be due to intrinsic host predilection in this group of bacteria, e.g. as commensals in healthy individuals with the potential for opportunistic systemic invasion of weakened hosts. Undoubtedly, wild wrasse captured and held in captivity are subjected to significant stress, which could render them immunocompromised and susceptible to infectious disease. These matters require further investigation, however, before conclusions can be drawn. An extended full-scale challenge trial was nevertheless in this case deemed ethically unacceptable in relation to the limited gains in knowledge anticipated.

In summary, the present study found that examined $V$. tapetis isolates cultured from wrasse used as cleaner fish in Norwegian salmon farms belonged exclusively to the subspecies tapetis, and that 4 dis- 
tinct serotypes (O1, O3, O4 and O5) dominated. While this may reflect host specificity, a pilot challenge trial in ballan wrasse using i.p. injection with 3 of the serotypes did not support pathogenicity towards this fish species.

Acknowledgements. This work was funded in equal part by Vaxxinova Norway and The Research Council of Norway (NFR; Grant No. 226695/O30).

\section{LITERATURE CITED}

Anisimova M, Gascuel O (2006) Approximate likelihoodratio test for branches: a fast, accurate, and powerful alternative. Syst Biol 55:539-552

Balboa S, Romalde JL (2013) Multilocus sequence analysis of Vibrio tapetis, the causative agent of brown ring disease: description of Vibrio tapetis subsp. britannicus subsp. nov. Syst Appl Microbiol 36:183-187

Balboa S, Prado S, Beaz R, Barja JL, Romalde JL (2006) Biochemical, serological and genetical intraspecific diversity in the clam pathogen Vibrio tapetis. In: Proc 5th Int Symp Aquatic Animal Health, 2-6 September 2006, San Francisco, CA

Bergh Ø, Samuelsen OB (2007) Susceptibility of corkwing wrasse Symphodus melops, goldsinny wrasse Ctenolabrus rupestis, and Atlantic salmon Salmo salar smolt, to experimental challenge with Vibrio tapetis and Vibrio splendidus isolated from corkwing wrasse. Aquacult Int 15:11-18

Bornø G, Lie Linaker M (eds) (2015) The health situation in Norwegian aquaculture 2014. Norwegian Veterinary Institute, Harstad

Declercq AM, Chiers K, Soetaert M, Lasa A and others (2015) Vibrio tapetis isolated from vesicular skin lesions in Dover sole Solea solea. Dis Aquat Org 115:81-86

Guindon S, Dufayard JF, Lefort V, Anisimova M, Hordijk W, Gascuel O (2010) New algorithms and methods to estimate maximum-likelihood phylogenies: assessing the performance of PhyML 3.0. Syst Biol 59:307-321

Gulla S, Sørum H, Vågnes Ø, Colquhoun DJ (2015) Phylogenetic analysis and serotyping of Vibrio splendidusrelated bacteria isolated from salmon farm cleaner fish. Dis Aquat Org 117:121-131

Hjeltnes B (ed) (2014) The health situation in Norwegian aquaculture 2013. Norwegian Veterinary Institute, Oslo

Jensen S, Samuelsen OB, Andersen K, Torkildsen L and others (2003) Characterization of strains of Vibrio splendidus and $V$. tapetis isolated from corkwing wrasse

Editorial responsibility: Alicia Toranzo,

Santiago de Compostela, Spain
Symphodus melops suffering vibriosis. Dis Aquat Org 53: 25-31

Johansen R (ed) (2013) The health situation in Norwegian aquaculture 2012. Norwegian Veterinary Institute, Oslo

K Larkin MA, Blackshields G, Brown NP, Chenna R and others (2007) Clustal W and Clustal X version 2.0. Bioinformatics 23:2947-2948

Kevican A, Lasa A, Irgang R, Romalde JL, Poblete-Morales M, Avendaño-Herrera R (2017) Isolation of Vibrio tapetis from two native fish species (Genypterus chilensis and Paralichthys adspersus) reared in Chile and description of Vibrio tapetis subsp. quintayensis subsp. nov. Int $\mathrm{J}$ Syst Evol Microbiol 67:716-723

* López JR, Balboa S, Núñez S, de la Roca E and others (2011) Characterization of Vibrio tapetis strains isolated from diseased cultured wedge sole (Dicologoglossa cuneata Moreau). Res Vet Sci 90:189-195

Nilsen A, Viljugrein H, Røsæg MV, Colquhoun D (2014) Rensefiskhelse-kartlegging av dødelighet og dødelighetsårsaker [Cleaner fish health - a survey of mortalities and causes of death]. Report Series 12, Norwegian Veterinary Institute, Oslo (in Norwegian)

Norwegian Directorate of Fisheries (2015) Norwegian aquaculture statistics. www.fiskeridir.no/English/Aquaculture/ Statistics

Paillard C (2004) A short-review of brown ring disease, a vibriosis affecting clams, Ruditapes philippinarum and Ruditapes decussatus. Aquat Living Resour 17:467-475

* Reid HI, Duncan HL, Laidler LA, Hunter D, Birkbeck TH (2003) Isolation of Vibrio tapetis from cultivated Atlantic halibut (Hippoglossus hippoglossus L.). Aquaculture 221: 65-74

Skiftesvik AB, Durif CMF, Bjelland RM, Browman HI (2015) Distribution and habitat preferences of five species of wrasse (Family Labridae) in a Norwegian fjord. ICES J Mar Sci 72:890-899

Stackebrandt E, Frederiksen W, Garrity GM, Grimont PAD and others (2002) Report of the ad hoc committee for the re-evaluation of the species definition in bacteriology. Int J Syst Evol Microbiol 52:1043-1047

* Suau A, Bonnet R, Sutren M, Godon JJ, Gibson GR, Collins MD, Doré J (1999) Direct analysis of genes encoding 16S rRNA from complex communities reveals many novel molecular species within the human gut. Appl Environ Microbiol 65:4799-4807

* Tamura K, Stecher G, Peterson D, Filipski A, Kumar S (2013) MEGA6: molecular evolutionary genetics analysis version 6.0. Mol Biol Evol 30:2725-2729

Wildschutte H, Preheim SP, Hernandez Y, Polz MF (2010) $\mathrm{O}$-antigen diversity and lateral transfer of the wbe region among Vibrio splendidus isolates. Environ Microbiol 12: 2977-2987

Submitted: April 11, 2016; Accepted: May 15, 2017

Proofs received from author(s): July 28, 2017 